Agro-Science Journal of Tropical Agriculture, Food, Environment and Extension Volume 15 Number 1 January, 2016 pp. 39-44

ISSN 1119-7455

\title{
EVALUATION OF THE GROWTH PERFORMANCE, CARCASS CHARACTERISTICS AND BLOOD INDICES OF BROILER FINISHERS FED GRADED LEVELS OF FERMENTED Mucuna sloanei SEED MEAL
}

\author{
Okorie, K.C., Esiegwu*, A.C. and Okonkwo U.N. \\ Department of Animal Science \& Fisheries, Imo State University, P.M.B. 2000 Owerri - Nigeria \\ *Corresponding author’s email: arthuresiegwu@ yahoo.com
}

\begin{abstract}
An experiment was conducted to determine the effect of Fermented Mucuna Sloanei Meal (FMSM) on growth, carcass characteristics and blood indices of finisher broilers. Fermented Mucuna Sloanei seeds were processed into meal and analyzed for proximate and phytochemical compositions. The meal was then used to make four broiler finisher diets at 0, 5.0, 10.0, and 15.0\% inclusion levels, respectively. Each diet was fed to a group of 30 finisher broilers at 5 weeks old for 28 days using completely randomized design. Each group was further subdivided into three replicates of 10 birds each. Average daily feed intake and average daily weight gain decreased significantly $(p<0.05)$ as the dietary levels of Fermented Mucuna Sloanei Meal increased. Feed conversion ratio increased significantly as the dietary levels of Fermented Mucuna Sloanei Meal increased. Cost of production was significantly increased $(p<0.05)$ as Fermented Mucuna Sloanei Meal increased. The dressed weight and breast weight were significantly decreased $(p<0.05)$ with dietary inclusion of Fermented Mucuna Sloanei Meal. The heart, the liver and gizzard were significantly increased $(p<0.05)$ as the inclusion of Fermented Mucuna Sloanei Meal increased. The haemoglobin, packed cell volume, mean cell volume, mean cell haemoglobin concentration, Erythrocyte sedimentation rate, white blood cell and the differentials (lymphocytes, monocytes, neutrophils, eosinophils and basophils) were not affected by treatments ( $p>0.05$ ). The urea concentration and the liver enzymes (alanine amino transaminase, serum glutamate oxaloacetate transaminase and serum glutamate pyruvate transaminase) were not affected by dietary treatment. Blood indices affected were red blood cell, total proteins and creatinine which decreased significantly $(p<0.05)$ as the dietary inclusion of Fermented Mucuna Sloanei Meal increased. Therefore, replacement of soya bean with Fermented Mucuna Sloanei Meal should not exceed 5\% dietary level.
\end{abstract}

Key words: blood indices, carcass, fermented mucuna, growth

\section{INTRODUCTION}

The most critical challenge of the livestock and poultry industry is the provision of good quality feed for the animals. Quality feeds are expensive because most of the constituent feed materials such as soya bean, maize, fish meal and groundnut cake are utilized not only by the animals but by humans and industries as well. Competition for these feed items (especially protein feeds such as soya bean) hikes the price, leading to high cost of production and hence of poultry products. Soya bean is an oil seed legume, high in protein (44-47 crude protein) and forms the major source of plant protein for non-ruminants mainly poultry, constituting $20-30 \%$ level of inclusion in poultry ration (Opara and Okorie, 2015). The over dependence on soya bean as major protein source for monogastric animal feeding and industrial purposes has increased its scarcity and consequent high cost of production. There is need, therefore, to investigate into some other legume seeds that are rich in protein and have the potential to either partially or wholly replace soya bean in poultry ration and support the growth and life of the poultry industry.

Mucuna sloanei is one of the promising legumes that are rich in protein and may serve as an alternative to soya bean. The seeds are used in southeastern Nigeria as condiment and for soup thickening (Uzomah and Odusanya, 2011). Its seed yield is about $0.8-2.0 \mathrm{t} / \mathrm{ha}$ with crude protein of about 28\% (Aduku, 1993; Ijeh et al., 2004). Uzomah and Odusanya (2011) reported 23.92 crude protein, 3.18 crude fibre, 6.57 ether extract, 1.95 ash and 55.19 carbohydrate for Mucuna sloanei. Igbabul et al. (2012) reported different values for the proximate composition when fermented for varying durations: $13.12,15.31$ and $32.82 \%$ crude protein respectively for 24,48 and $72 \mathrm{~h}$ fermentation; crude fat was $6.0 \%$ (unfermented) and $6.5,4.0$ and $5.0 \%$ respectively for 24,48 and $72 \mathrm{~h}$ fermentation; ash was $1.8 \%$ (unfermented) and $1.6,0.8$ and $1.0 \%$ respectively for 24,48 and 72 h fermentation; while carbohydrate was $69.82 \%$ (unfermented) and 70.48, 72.29 and $51.59 \%$, respectively for 24,48 and $72 \mathrm{~h}$ fermentation. 
Evaluation of the Growth Performance, Carcass Characteristics and Blood Indices of Broiler Finishers Fed Graded Levels of Fermented Mucuna sloanei Seed Meal

One of the major constraints to legume utilization is the presence of anti-nutritional factors (Oke et al., 2002). Similar to other legumes, тисипа grains possess anti-nutritional factors such as L-dihydroxyphenylalanine, tannins, trypsin inhibitors etc. (Ukachukwu and Obioha, 1997; Akinmutimi and Okwu, 2006). There is need to process the seed in order to reduce the effect of these anti-nutrients. Fermentation is one of the traditional and most effective ways of detoxifying feed items before use. It is known to have added value to foods and has been reported to increase the soluble phenolic content of legumes, thereby enhancing its anti-oxidant activities (Oyarekua, 2011). Torres et al. (2006) reported a remarkable improvement in the nutritive value and quality of legume seeds through fermentation. Igbabul et al. (2012) also reported that fermentation increased the protein content, moisture and crude fibre content of the Mucuna sloanei flour.

This study therefore was aimed at investigating the effect of fermented Mucuna sloanei meal on the growth performance, carcass characteristics and blood indices of broiler finisher birds.

\section{MATERIALS AND METHODS}

\section{Source and Processing of Mucuna Seeds}

The Mucuna seeds were bought from a reputable source in Afo Oru market in Ahiazu Mbaise LGA of Imo State. The seeds were dehulled manually by cracking with hammer and the seeds were sorted to remove bad ones. Thereafter, the seeds were soaked in water for $72 \mathrm{~h}$. Water was changed daily. After $72 \mathrm{~h}$ fermentation, the seeds were washed and sun dried for seven days. The fermented dried seeds were milled into a fine powdery Mucuna sloanei meal. Samples of the meal were subjected to proximate and phytochemical analysis according to AOAC (2010).

\section{Experimental Diets}

Four finisher broiler diets were compounded, incorporating fermented Mucuna sloanei meal (FMSM) at 0, 5.0, 10.0 and $15.0 \%$ inclusion levels partly replacing soya bean in the control diet. The diets were designated as $\mathrm{T}_{0}, \mathrm{~T}_{5.0}, \mathrm{~T}_{10.0}$ and $\mathrm{T}_{15.0}$ respectively. The ingredient and calculated nutrient composition of the diets are shown in Table 1.

\section{Experimental Birds and Design}

One hundred and twenty (120) delight super strain broiler chicks bought from a reputable dealer in Owerri were used for the trial. The birds were randomly divided into four groups of 30 broilers and each group randomly assigned to one of the four treatment diets in a completely randomized design (CRD). Each group was further subdivided into three replicates of 10 broilers each and each replicate housed in a deep litter compartment measuring $1 \mathrm{~m} \times 1.5 \mathrm{~m}$. Feed and water were provided ad libitum. The trial lasted for 28 days.
Table 1: Ingredient composition of the experimental diets in $(\mathrm{kg})$

\begin{tabular}{lcccc}
\hline & \multicolumn{4}{c}{ Treatments (Dietary levels) } \\
\cline { 2 - 5 } Ingredients & $\mathrm{T}_{1}$ & $\mathrm{~T}_{2}$ & $\mathrm{~T}_{3}$ & $\mathrm{~T}_{4}$ \\
\hline Maize & 58 & 58 & 58 & 58 \\
Soya bean & 15 & 10 & 5 & 0 \\
Mucuna sloanei & 0 & 5 & 10 & 15 \\
Groundnut cake & 9 & 9 & 9 & 9 \\
Fish meal & 2 & 2 & 2 & 2 \\
Blood meal & 2 & 2 & 2 & 2 \\
P.K.C. & 5.2 & 5.2 & 5.2 & 5.2 \\
Bone meal & 5 & 5 & 5 & 5 \\
*Vitamin. & 0.25 & 0.25 & 0.25 & 0.25 \\
premix & 0.30 & 0.30 & 0.30 & 0.30 \\
Common salt & 0.15 & 0.15 & 0.15 & 0.15 \\
L-Lysine & 0.10 & 0.10 & 0.10 & 0.10 \\
Methionine & 3 & 3 & 3 & 3 \\
Wheat offal & &
\end{tabular}

Calculated nutrient composition of the experimental diets (\% dry matter)

\begin{tabular}{|c|c|c|c|c|}
\hline Crude protein & 20.07 & 19.59 & 19.10 & 18.62 \\
\hline Crude fibre & 3.91 & 3.31 & 3.63 & 3.45 \\
\hline Ether extract & 4.34 & 4.37 & 4.42 & 4.45 \\
\hline Phosphorous & 1.05 & 1.02 & 0.99 & 0.96 \\
\hline Calcium & 3.26 & 3.26 & 2.24 & 2.23 \\
\hline Di-Methionine & 0.36 & 0.33 & 0.30 & 0.27 \\
\hline L-Lysine & 0.89 & 0.79 & 0.69 & 0.59 \\
\hline $\begin{array}{l}\text { Metabolisable } \\
\text { energy }(\mathrm{kcal} / \mathrm{kg})\end{array}$ & 2873.88 & 2921.90 & 2969.92 & 3017.94 \\
\hline \multicolumn{5}{|c|}{$\begin{array}{l}\text { With the full meaning of FMSM as fermented Mucuna sloane } \\
\text { meal, } \mathrm{T}_{1}-0 \% \mathrm{FMSM} \text {; } \mathrm{T}_{2}-5.0 \% \mathrm{FMSM} \text {; } \mathrm{T}_{3}-10.0 \% \mathrm{FMSM} \text {; } \mathrm{T}_{4}-1 \\
15 \% \mathrm{FMSM} \text { *Provided the following per kg of feed; vit A, } \\
\text { 1000iu; vit D3, 1500iu; vit E } 51 \mathrm{mg} \text {; vit } \mathrm{K}, 2 \mathrm{mg} \text {; Riboflavin, } 3 \\
\mathrm{mg} \text {; Pantothenic acid, } 10 \mathrm{mg} \text {; Nicotinic acid, } 25 \mathrm{mg} \text {; Choline, } \\
350 \mathrm{mg} \text {; Folic acid, } 1 \mathrm{mg} \text {; Mg, } 56 \mathrm{mg} \text {; Iodine, } 1 \mathrm{mg} \text {; Fe, } 20 \mathrm{mg} \text {; } \\
\mathrm{Zn}, 50 \mathrm{mg} \text {; Co, } 1.25 \mathrm{mg}\end{array}$} \\
\hline
\end{tabular}

\section{Data Collection and Analysis}

The birds were weighed at the beginning of the experiment to obtain their initial body weights and then weekly thereafter. Daily feed intake was determined by subtracting the weight of leftover feed from the weight of the feed given the previous day. Data were collected on feed intake, body weight changes and feed conversion ratio. Feed conversion ratio was calculated as the average daily feed intake divided by average daily weight gain.

\section{Carcass Evaluation}

At the end of the four-week feeding trial, three birds were randomly selected from each treatment (one per replicate) and used for evaluation of the carcass and internal organ weights. The birds were starved of feed overnight and then slaughtered by severing the jugular vein with sharp knife after they have been weighed. The birds were defeathered and 
eviscerated. The live weights and dressed weights were recorded. Also weights of internal organs (liver, kidney, heart and gizzard) and length of intestine were taken and recorded and expressed as percentage of live weight.

\section{Haematology and Blood Biochemistry}

At the end of the 28-day feeding trial, blood samples were collected from 3 birds from each treatment and $2 \mathrm{mls}$ of blood placed in the specimen bottles with Ethylene diamine tetra acetic acid (EDTA) and $5 \mathrm{mls}$ of blood placed in the specimen bottle without EDTA for haematological and blood biochemical indices, respectively. Blood was analyzed within 3 hours of collection for red blood cell (RBC) count, haemoglobin concentration (HB), white blood cell count (WBC), packed cell volume (PCV), mean corpuscular haemoglobin $(\mathrm{MCH})$, mean cell haemoglobin concentration (MCHC), mean cell volume (MCV) and white blood cell, using standard methods (Monica, 1984). Blood biochemical indices analyzed included total protein, cholesterol, urea, creatinine, liver enzymes and the electrolytes sodium, potassium, carbonate and chloride (Monica, 1984).

\section{Statistical Analysis}

Data collected were subjected to analysis of variance as outlined by Snedecor and Cochran (1978) where analysis of variance indicated significant treatment effects; means were compared using Duncan's New Multiple Range Test (DNMRT) as outlined by Obi (1990).

\section{RESULTS AND DISCUSSION \\ Proximate Composition}

The proximate and phytochemical compositions of the fermented Mucuna sloanei meal are shown in Table 2. The crude protein content, ether extract and nitrogen free extract were very close to the values reported by Igbabul et al. (2012). The presence of anti-nutritional factors supports the report of Oke $e t$ al. (2002) and shows that fermentation did not completely eliminate the anti-nutrients.

Table 2: Proximate and phytochemical composition of fermented Mucuna sloanei meal

\begin{tabular}{lc}
\hline Constituents & Amount Mg/100g (\% DM) \\
\hline Moisture & 8.0 \\
Crude protein & 34.3 \\
Ether extract & 4.27 \\
Nitrogen free extract & 49.73 \\
Crude fibre & 1.7 \\
Ash & 2.0 \\
ME (kcal/kg) & 3380.38 \\
Phytochemical composition & \\
Tannins & 1.42 \\
Alkaloids & 1.4 \\
Flavonoids & 7.96 \\
Cardiac glucosides & 9.41 \\
Phytate & 0.73 \\
Phenols & 0.78 \\
Saponins & 1.0 \\
\hline
\end{tabular}

\section{Performance of Finisher Broilers}

The performance of the experimental broiler finishers birds is shown in Table 3. Average daily body weight changes and average daily feed intake decreased significantly $(\mathrm{p}<0.05)$ as the dietary levels of fermented Mucuna sloanei meal (FMSM) increased. Feed conversion ratio increased significantly $(\mathrm{p}<0.05)$ as the dietary intake of FMSM increased. The significant depression in feed intake and body weight gain as the dietary level of FMSM increased could be attributed to the presence of anti-nutritional factors such as tannin and saponin. Saponin has been reported to possess some bitterness (Sodipo and Akiniyi, 2000; Okwu, 2004) and caused retardation of growth rate due to a reduction in feed intake in poultry, rats, rabbits and swine (Cheeke and Shull, 1985). In rabbit and rat, condensed tannin from the browse plant Robin's pseudoacacia caused reduced feed intake, reduced growth and coprophogy (Raharjo et al., 1990) and reduced protein digestibility (Horigone et al., 1988). Consequently, the values for the feed conversion ratio increased as intake of FMSM increased. The feed cost per $\mathrm{kg}$ weight gain also increased as the inclusion levels of FMSM increased. The fermented Mucuna sloanei meal even at 5\% dietary levels showed poor performance relative to the control $(p<0.05)$ for average daily weight gain and more so feed cost per kg weight gain increased tremendously. This finding supports the report of Akinmutimi and Essien (2011) that dehulled Mucuna sloanei meal could not replace soya bean meal even at 5\% dietary level of inclusion.

\section{Carcass Characteristics}

The carcass and internal organ weights are shown in Table 4. The dressed weight and breast weight decreased significantly as the dietary levels of FMSM increased. The decrease in the breast weight (\% live weight) of the group fed FMSM was an indication that nutrients required for tissue synthesis were not sufficient. This could be attributed to poor utilization of protein due to the presence of anti-nutritional factors such as Ldihydroxyphenylalanine and tannin. Tannin is reported to form complexes with dietary proteins (Vaithiyanathan and Kumar, 1993) as well as endogenous proteins including enzymes and this may inhibit the actions of proteolitic enzyme from undergoing normal metabolism of proteins. Matthew et al. (2010) reported that higher percentage breast indicated better protein utilization by birds. The dressed percentage (69.69 to $73.51 \%)$ were within the range $(60.30-74.65 \%)$ recommended for broiler chickens (Bangbose and Niba, 1998). The control gave best dressing percentage which was an indication that higher dietary energy gave higher percentage dressed weight (Igwuene, 2013). The heart was significantly increased $(\mathrm{p}<0.05)$ at $15 \%$ dietary level. This could be attributed to the toxic effect of 
the Mucuna seeds. $15 \%$ dietary level or more is capable of causing or stimulating cardiac hypertrophy. The weight of the liver increased significantly $(\mathrm{p}<0.05)$ with the dietary inclusion of FMSM. The enlargement of these organs could be due to increased metabolic activities of the liver in trying to make up for reduced availability of proteins due to presence of anti-nutritional factors (Omeje, 1999; Marty and Chavez, 1993; Matthew et al., 2010). The findings support the report that liver is a major detoxification organ and hence increase in its activities may result in enlargement and probably increased weight (Akinmutimi, 2004; Akinmutimi, 2011).

\section{Haematology and Blood Biochemistry}

The results of the haematological and blood biochemical indices of FMSM are presented in Table 5. Apart from red blood cell that was significantly influenced $(p<0.05)$ by dietary treatments, all other haematological parameters measured were not significant $(p>0.05)$. There was no significant treatment $(\mathrm{p}>0.05)$ effect in all the serum biochemical indices examined except the total proteins and creatinine which were significantly influenced $(\mathrm{p}<0.05)$ by dietary treatments. Red blood cell decreased significantly $(\mathrm{p}<0.05)$ at $15 \%$ dietary level of inclusion. Low values of red blood cell could be an indication of anaemia (Mohammed and Oloyede, 2009). Low value of red blood cell at $15 \%$ dietary level could be due to the toxins from the test material as a result of anti-nutrients. White blood cell that was statistically similar was a sign of absence of any specific infection from the feed. Total proteins decreased significantly $(\mathrm{p}<0.05)$ with the dietary inclusion of FMSM. This could be attributed to the anti-nutrient - tannin that forms complexes with protein thereby making it unavailable. The globulin and albumin decreased significantly with the inclusion of FMSM. Globulins are carriers of certain metals through the blood stream to various parts of the body that helps to fight infection. Globulin often rises with heavy infections because of increased production of antibodies. The decrease in globulin level was an indication of absence of infection arising from the test feed. Low values of creatinine could mean that there was no muscle wastage (Ukpabi et al., 2015).

Table 3: Performance of the experimental broiler finisher birds

\begin{tabular}{|c|c|c|c|c|c|}
\hline \multirow[b]{2}{*}{ Parameters } & \multicolumn{5}{|c|}{ Dietary level of FMSM } \\
\hline & T0.0 & T5.0 & T10.0 & $\mathrm{T} 15.0$ & SEM \\
\hline Average initial body weight (g) & 860 & 850 & 850 & 870 & 10.2 \\
\hline Average final body weight (g) & $2370^{\mathrm{a}}$ & $1900^{\mathrm{b}}$ & $1750^{\mathrm{c}}$ & $1470^{\mathrm{d}}$ & 23.3 \\
\hline Average daily weight gain (g) & $68^{\mathrm{a}}$ & $48^{\mathrm{b}}$ & $39 b^{c}$ & $27^{\mathrm{c}}$ & 4.93 \\
\hline Average daily feed intake (g) & $187^{\mathrm{a}}$ & $180^{\mathrm{b}}$ & $172^{\mathrm{c}}$ & $156^{\mathrm{d}}$ & 0.58 \\
\hline Feed conversion ratio & $2.75^{\mathrm{c}}$ & $3.76^{\mathrm{bc}}$ & $4.36^{\mathrm{b}}$ & $5.78^{\mathrm{a}}$ & 0.37 \\
\hline Feed cost (N/kg) & 94.86 & 110.92 & 143.5 & 167.82 & \\
\hline Feed cost per kg weight gain & 260.82 & 417.06 & 625.75 & 970.12 & \\
\hline
\end{tabular}

abcd means within the same row with different superscripts are significantly different $(\mathrm{P}<0.05)$

Table 4: Carcass and internal organ characteristics of the experimental finisher broiler birds

\begin{tabular}{|c|c|c|c|c|c|}
\hline \multirow[b]{2}{*}{ Parameters } & \multicolumn{5}{|c|}{ Dietary level of FMSM (\%) } \\
\hline & $\mathrm{T}_{1}(0 \%)$ & $\mathrm{T}_{2}(5.0 \%)$ & $\mathrm{T}_{3}(10.0 \%)$ & $\mathrm{T}_{4}(15.0 \%)$ & SEM \\
\hline Live weight $(\mathrm{kg})$ & $2.27^{\mathrm{a}}$ & $1.80^{\mathrm{b}}$ & $1.65^{\mathrm{b}}$ & $1.37^{\mathrm{c}}$ & 0.04 \\
\hline Dressed weight (\% live weight) & $73.51^{\mathrm{a}}$ & $72.20^{\mathrm{b}}$ & $71.53^{\mathrm{b}}$ & $71.00^{\mathrm{b}}$ & 0.50 \\
\hline Breast weight (\% live weight) & $20.34^{\mathrm{a}}$ & $17.35^{\mathrm{ab}}$ & $18.30^{\mathrm{ab}}$ & $16.59^{\mathrm{b}}$ & 1.16 \\
\hline Thigh/Drumstick (\% live weight) & 22.21 & 18.63 & 22.06 & 21.79 & 2.35 \\
\hline Wing (\% live weight) & 8.09 & 8.94 & 7.64 & 9.85 & 1.07 \\
\hline Neck (\% live weight) & 3.56 & 4.67 & 5.67 & 6.29 & 1.24 \\
\hline Head (\%live weight) & 3.20 & 3.43 & 3.68 & 4.02 & 0.48 \\
\hline Back (\% live weight) & $14.86^{\mathrm{a}}$ & $13.75^{\mathrm{b}}$ & $13.80^{\mathrm{b}}$ & $11.50^{\mathrm{c}}$ & 0.01 \\
\hline Heart (\%live weight) & $1.04^{\mathrm{b}}$ & $1.88^{\mathrm{ab}}$ & $1.53^{\mathrm{ab}}$ & $2.55^{\mathrm{a}}$ & 0.44 \\
\hline Liver weight (\% live weight) & $1.74^{\mathrm{c}}$ & $3.15^{\mathrm{a}}$ & $2.00^{\mathrm{bc}}$ & $3.42^{\mathrm{a}}$ & 0.39 \\
\hline Gizzard (\% live weight) & $2.28^{\mathrm{b}}$ & $3.54^{\mathrm{ab}}$ & $2.77^{\mathrm{ab}}$ & $3.91^{\mathrm{a}}$ & 0.50 \\
\hline Kidney (\% live weight) & 0.16 & 0.18 & 0.18 & 0.19 & 0.02 \\
\hline Intestinal length $(\mathrm{cm})$ & $182^{\mathrm{a}}$ & $177^{\mathrm{ab}}$ & $173^{\mathrm{ab}}$ & $156^{\mathrm{b}}$ & 8.29 \\
\hline
\end{tabular}


Table 5: Serum biochemical indices of the experimental finisher broiler birds

\begin{tabular}{|c|c|c|c|c|c|}
\hline \multirow[b]{2}{*}{ Parameters } & \multicolumn{5}{|c|}{ Dietary levels of fermented mucuna sloanei meal (\%) } \\
\hline & $T_{1}(0)$ & $T_{2}(5)$ & $\mathrm{T}_{3}(10)$ & $\mathrm{T}_{4}(15)$ & SEM \\
\hline Haemoglobin (Hb) g/dl) & 13.0 & 12.7 & 12.4 & 12.2 & 3.01 \\
\hline Packed cell volume (PCV) \%) & 42.7 & 40.6 & 40.0 & 38.7 & 1.32 \\
\hline Red blood cell (RBC) $\left(\times 10^{12} / \mathrm{L}\right)$ & $12.9^{\mathrm{a}}$ & $12.8^{\mathrm{a}}$ & $12.3^{\mathrm{a}}$ & $11.8^{\mathrm{b}}$ & 0.29 \\
\hline Mean cell volume (MCV)(FL) & 32.4 & 31.7 & 32.9 & 32.6 & 3.01 \\
\hline Mean cell haemoglobin concentration (g/dl) & 30.4 & 31.6 & 30.9 & 31.6 & 0.54 \\
\hline Mean cell haemoglobin (pg) & 10.1 & 10.0 & 10.2 & 10.2 & 0.10 \\
\hline Erythrocyte sedimentation rate $\left(\mathrm{mm}^{3} / 1^{\text {st }} 1 \mathrm{hr}\right)$ & 13.7 & 14.7 & 12.7 & 13.0 & 1.12 \\
\hline White blood cell count $\left(\times 10^{9} / \mathrm{L}\right)$ & 11.5 & 11.4 & 11.3 & 11.1 & 0.23 \\
\hline Lymphocytes (\%) & 43.6 & 43.3 & 44.3 & 43.6 & 028 \\
\hline Neurophilis (\%) & 53.0 & 54.0 & 52.5 & 53.3 & 1.31 \\
\hline Eosinphils (\%) & 1.6 & 1.6 & 1.3 & 1.3 & 0.22 \\
\hline Monocytes $(\%)$ & 1.6 & 1.4 & 1.2 & 1.3 & 0.30 \\
\hline Basophils (\%) & 0 & 0 & 0 & 0 & 0.00 \\
\hline \multicolumn{6}{|c|}{ Serum biochemical indices of the experimental finisher broiler birds } \\
\hline Total proteins (g/dl) & $6.5^{\mathrm{a}}$ & $6.03^{\mathrm{a}}$ & $5.93^{\mathrm{b}}$ & $5.65^{\mathrm{b}}$ & 0.13 \\
\hline Albulin (s/dl) & $2.30^{\mathrm{a}}$ & $2.13^{\mathrm{b}}$ & $2.00^{\mathrm{b}}$ & $2.06^{\mathrm{b}}$ & 0.55 \\
\hline Globulin (s/dl) & $4.02^{\mathrm{a}}$ & $3.90^{\mathrm{ab}}$ & $3.93^{\mathrm{ab}}$ & $3.56^{\mathrm{b}}$ & 1.18 \\
\hline Arsinine (s/dl) & 1.20 & 1.40 & 1.20 & 1.93 & 0.21 \\
\hline Urea concentration $(\mathrm{mmol} / \mathrm{L})$ & 9.0 & 8.63 & 8.60 & 8.0 & 1.92 \\
\hline Cholesterol (mmol/L) & 10.4 & 10.07 & 9.87 & 9.53 & 0.26 \\
\hline Creatinine (mmol/L) & $2.50^{\mathrm{a}}$ & $2.33^{\mathrm{b}}$ & $2.06^{\mathrm{c}}$ & $2.10^{\mathrm{c}}$ & 0.03 \\
\hline Sodium (mmol/L) & 43.33 & 41.33 & 41.0 & 40.67 & 1.00 \\
\hline Potassium (mmol/L) & 1.33 & 1.23 & 1.27 & 0.97 & 0.12 \\
\hline Carbonate (mmol/L) & 11.2 & 11.1 & 10.7 & 10.8 & 0.22 \\
\hline Chloride (mm0ol/L) & $25.0^{\mathrm{a}}$ & $22.67^{b}$ & $22.67^{b}$ & $21.33^{\mathrm{c}}$ & 1.38 \\
\hline ALT (iu/L) & 1.36 & 1.23 & 1.30 & 1.26 & 0.05 \\
\hline SGOT (iu/L) & 12.07 & 12.00 & 11.50 & 11.57 & 0.33 \\
\hline SGPT (iu/L) & 7.43 & 7.23 & 6.87 & 6.90 & 0.13 \\
\hline
\end{tabular}

\section{CONCLUSION}

The results of the trial have shown that fermented Mucuna sloanei meal could not serve as a good replacement to soya bean in broiler feed even at $5 \%$ dietary level because of poor weight gain, poor feed conversion ratio and high cost of feed per $\mathrm{kg}$ weight gain.

\section{REFERENCES}

Aduku, A.O. (1993). Tropical feedstuff analysis table. Department of Animal Science, Ahmadu Bello University, Samaru Zaria, Kaduna State, Nigeria

Akinmutimi, A.H. (2004). Effect of cooking periods on the nutrient composition of Mucuna utilis seeds. Nigerian Poultry Science Journal, 2\&3, 44-51

Akinmutimi, A.H. and Okwu, N.D. (2006). Effect of quantitative substitution of cooked Mucuna utilis seed meal for soya bean meal in broiler finisher diet. Int. Journal of Poultry Science, 5 (5), 477-481

Akinmutimi, A.H., Edet, J.D., Okocha, C.N. and Odoemelam, V.N. (2011). The evaluation of toasted Mucuna sloanei meal as a feed ingredient in broiler diet. International Journal of Current Research, 13 (4), 120-126
Akinmutimi, A.H. and Essien, U.N. (2011). Performance of broiler chickens fed graded levels of dehulled Mucuna sloanei meal in place of soya bean. Int. Journal of Current Research, 3 (4), 127-132

Aletor, V.A. (1989). Effect of varying levels of fish meal substitution with soya bean meal on certain serum metabolism. Nigerian J. Technol. Res., 1, 111-114

Aletor, V.A. and Egberougbe, O. (1992). Feeding differently processed soya beans part 2 . An assessment of haematological responses in the chicken diets. Nahrug, 36 (4), 364-369

AOAC (2010). Official Methods of Analysis. $19^{\text {th }}$ edition. Association of Official Analytical Chemists. Washington D.C., USA

Bangbose, A.M. and Niba, A.T. (1998). The Nigerian livestock industry in the $21^{\text {st }}$ century. Third Annual Conference of Animal Science Association of Nigeria (ASAN), pp. 84-87

Cheeke, P. R and Shull, I. R. (1985). Natural toxicants in feeds and poisonous plants. AVI Publishing Inc., West Port, Connecticut

Horigan, T., Kumar, R. and Okamoto, K. (1988). Effects of condensed tannins prepared from the leaves of fodder plants on digestive enzymes in vitro and in the intestine of rats. British Journal of Nutrition, 60, 275-285 
Evaluation of the Growth Performance, Carcass Characteristics and Blood Indices of Broiler Finishers Fed Graded Levels of Fermented Mucuna sloanei Seed Meal

Igbabul, B.D., Idikwu, H.O. and Inyang C.U. (2012). Effect of fermentation on some functional properties of Mucuna sloanei and Detarium microcarpum. Journal of Food Technology. 10(3): 83-86

Ijeh, I.I., Unaegbu, S.O. and Anaga, A.O. (2004). Studies on some nutritional and toxicological properties of Mucuna sloanei. African Journal of Online Bioresearch, 2 (1), 24-28

Marty, B.J. and Chavez, E.R. (1993). Effect of heart processing on digestibility of energy and other nutrient digestibility of full fat soya beans fed to weamer, grower and finisher pigs. Can. J. of Animal Science, 73, 411-419

Matthew, U.D., Tegbe, T.S.B., Omage, J.J., and Adeyinka, I.A. (2010). The effect of duration of cooking pigeon pea (cajanus cajan) seeds on the performance and carcass characteristics of broiler chicks. Nig. J. of Animal Science, 37 (1), 13-24

Mohammed, N.O. and Oloyede, O.B. (2009). Growth performance of broiler chicks fed Aspergillus nigerfermented terminalia catappa seed meal based diet. Global Journal of Biotechnology \& Biochemistry, 4 (2), 179-183

Monica, C. (1984). Medical Laboratory Manual for Tropical Countries. Vol II. Microbiology ELBS edition

Obi, I.U. (1990). Statistical Methods of Detecting Differences between Treatment Means. $2^{\text {nd }}$ edition, Snap Press, Enugu, Nigeria

Omeje, S.I. (1999). Issues in animal science. Proceedings of $29^{\text {th }}$ Annual Conference of the Nigeria Society of Animal Production, 28, pp. 240-244. Ray Kennedy Scientific Publications, Enugu, Nigeria

Oke, D.B., Oke, M.O. and Adeyemi, O.A. (2002). Predictions of cow pea seed protein quality through total sulphure determination. Proceedings of $7^{\text {th }}$ Annual Conference of Animal Science Association of Nigeria. Sept. $16-19^{\text {th }}, 2002$, p. 121

Okwu, D.E. (2004). Phytochemical and vitamin contents of indigenous spices of south eastern Nigeria. $J$. of Sustain Agric. Environ., 6, 30-34

Opara, A.U. and Okorie, K.C. (2015). Effect of cooked Mucuna sloanei seed meal on the performance, carcass characteristics and apparent nutrient digestibility on broiler finisher birds. International Journal of Agricultural Bioscience, 4 (4), 145-149
Oyerekun, M.A. (2011). Biochemical and microbiological changes during the production of fermented pigeon pea (cajanus cajan) flour. Afr. $J$. Biotech, 2, 223-231

Rahorjo, Y.C., Cheeke, P.R. and Patton, N.M. (1990). Effect of Cecotrophy on the nutrient digestibility of alfalfa and blank locust leaves. Journal of applied Rabbit Research. 13: 56-61

Snedeccor, G.W. and Cochran, W.G. (1978). Statistical methods. The IOWA State University press, AmesIOWA, $6^{\text {th }}$ Edition

Sodipo, O.A. and Akiniyi, J.A. (2000). Studies on certain characteristics of extracts from bark of pansinystalia macruceras (k.schum) pierre Exbeil. Global Journal of Pure and Applied Sciences, 6, 83-87

Torres, A. Frias, J., Granito, M. and Vidal-Valverde, C. (2006). Fermented pigeon pea (cajanus cajan) ingredients in paste products. Journal of Agricultural Food Chemical, 54, 6685-6691

Ugwuene, M.C. (2013). Response of broiler, turkeys to graded dietary levels of palm kernel meal in replacement for maize. Nigeria Journal of Animal Production. 40 (2), 21-29

Ukachukwu, S.N. and Obioha, F.C. (1997). Chemical evaluation of Mucuna Conchichinonsis as alternative protein feedstuff. Journal of Applied Chemistry and Agricultural Research, 4, 33-38

Ukpabi, U.H., Mbachu, C.L. and Nwazue, B. (2015). Effect of inclusion of different levels of raw Adenanthera Pavonina Seed Meal (RAPSM) on Haematology and Blood Chemistry of Finisher Broilers. Nigerian J. Anim. Sci. 17 (1), 28-36

Uzomah, A. and Odusanya, O. S (2011). Mucuna sloanei, detarium microcarpum and Brachastegia eurycoma seeds: a preliminary study of their starch hydrocolloids system. African Journal of Food Science, 5 (13), 733-740

Viathyanathan, S. and Kumar, R. (1993). Relationship between protein precipitating capacity of fodder tree leaves and their tannin content. Animal Food Science and Technology, 44, 281- 287 